\title{
Teacher Technology Uptake in Indonesian EFL Classes
}

\author{
Delpani Selpia*, Pupung Purnawarman \\ Faculty of Language and Literature Education, Universitas Pendidikan Indonesia, Bandung \\ *Corresponding author. Email: delpaniselpia@upi.edu
}

\begin{abstract}
Technology is becoming increasingly integrated into teaching environments in terms of enhancing students engagement and facilitating teaching. Technology as one of the important tools in helping the success of 21st-century learning requires students to use it appropriately in accessing information. Equally important is that teachers are expected to be more adept at empowering technology in classroom learning. This paper reveals the results of a study investigating EFL teachers' computer and internet use as an aid to teaching and their reasons for integrating or ignoring technology use when teaching. This study involved 50 English teachers who teach in Junior (JHS) and senior high schools (SHS) in one province in Indonesia. The data were collected through questionnaires containing statements related to the teachers' computer and the internet use in teaching and follow-up Focus Group Interviews (FGI) to explore their reasons for integrating or ignoring the technology use when teaching. Conclusions and suggestions are then presented for EFL teaching using technology and further research as well.
\end{abstract}

Keywords: EFL, technology, uptake

\section{INTRODUCTION}

Technology integration is defined as the effective implementation of educational technologies to accomplish intended learning outcomes Davies and West (2014). ICT has been integrated into ESL and EFL learning since the 1960s but is limited to specific skills (Chapelle, 2003). In this 21st century, technology integration in teaching and learning becomes more popular and demanding where any information can easily be obtained through gadgets, the internet, and other sophisticated digital media. It has become a normal part of ELT practice nowadays.

There has been considerable proof in the literature as to why ICT should be integrated into language learning programs. Since internet access is mostly available in many places and is increasingly accessible to learners, technology must be empowered so that student learning becomes more efficient and meaningful (Billah, 2015). Further, technology nowadays has been introduced since childhood, and children are growing up with them, and it is a natural and integrated part of their lives (Billah, 2015). Moreover, technology creates an interactive atmosphere in the classroom, motivates students, and provides authentic language input for students (Cahyani $\&$ Cahyono, 2012).
The word internet, which usually goes with the word technology, is accessed by almost all people started with children. Students may be more proficient and more interested in using technology in their daily lives as digital natives. Therefore, teachers should be more agile and more competent in utilizing technology in teaching because it is closely related to students' real-life experiences. Teaching by using technology must be carried out by teachers by having some adequate competencies involving: (1) fostering students' technological literacy (Warschauer \& Healey, 1998), (2) not only delivering the content of their subject, but also teaching and modeling technology use, pedagogical beliefs, and instructional strategies (Bai \& Ertmer, 2008; Garcia \& Rose, 2007), and (3) connecting aspects of technology, pedagogy, and content as well as the underlying relationships (Koster, Dengerink, Korthagen, \& Lunenberg, 2008). Accordingly, teachers are required not only to be proficient in using technology but also to integrate technology with learning.

Notwithstanding such high demands for teachers to use technology in learning, including in language learning, several factors cause the low use of technology in the classroom. Access or quality of facilities, the vision of school administration, teacher beliefs, and the time required for preparation and professional development are some factors that underlie this 
(Kopcha, 2012). Other factors are teaching experience (Cuban, Kirkpatrick \& Peck, 2001) and teacher knowledge and skills (Pelgrum, 2001). Even though these factors seem to linger, encouraging the use of technology in teaching is crucial and recommended for teachers, especially EFL teachers, given the ease it offers as a medium for delivering second and foreign language learning.

In Indonesia, the use of technology as a medium for teaching English as a foreign language is highly recommended in the 2013 curriculum which is the curriculum currently in use. Utilization of Information and Communication Technology is encouraged in the Regulation of the Minister of Education and Culture of the Republic of Indonesia Number 65 of 2013a concerning Basic and Secondary Education Process Standards in paragraph 13 regarding the use of information and communication technology to improve the efficiency and effectiveness of learning (Billah, 2015). Based on the emphasis on teaching integrated with technology, this study aims to reveal Indonesian EFL teachers' computer and internet use as an aid to teaching. Second, it intends to explore the teachers' reasons for integrating or ignoring the technology use when teaching.

\section{METHOD}

\subsection{Research Design}

This study is descriptive qualitative research since it aims to find out Indonesian EFL teachers' technology use, computer and internet in particular, as well as to explore the reasons of those who integrated them in teaching and those who did not. In this case, this research only answers the questions "what" and "how"

\subsection{Participants}

The participants of the current research were 50 English teachers who teach in Junior High Schools (JHS) and senior high schools (SHS) in West Sumatera, Indonesia. Those teachers have a variety of different educational backgrounds. Subsequently, 10 teachers were selected based on those who integrated technology (5 teachers) and those who did not use technology in their teaching (5 teachers).

\subsection{Data Collection and Analysis}

The data in this study were collected through questionnaires and interviews. Online questionnaires adapted from Li and Walsh (2011) were distributed to those 50 teachers through Google Form to investigate their computer and internet use as an aid to teaching. Then, Focus Group Interviews or FGI were also conducted with 5 teachers who used computers and the internet in their teaching and 5 other teachers who did not use both computers and the internet when teaching in the classroom. The data collected through Google Forms and FGI were then analysed quantitatively and qualitatively. The quantitative data were presented in the form of the percentage of the teachers' computer and internet use in teaching. Meanwhile, the qualitative data were elaborated in the form of statements from the teachers' reasons for integrating or ignoring the use of technology when teaching. These data were analysed based on an extensive review of the technology uptake literature. The data of the respondents are presented in Table 1.

\section{FINDINGS AND DISCUSSION}

\subsection{Findings}

The following paragraphs centre on the discussion of the results of the questionnaire analysis on the participants' computer and internet use in teaching. The next section will present the data analysed qualitatively about the teachers' reasons for integrating or ignoring the use of technology when teaching.

Table 1. Demographic characteristics of the participants for questionnaires

\begin{tabular}{|c|c|c|}
\hline & Respondents & Percentage \\
\hline \multirow[t]{2}{*}{ Gender } & Male & $68 \%$ \\
\hline & Female & $32 \%$ \\
\hline \multirow[t]{3}{*}{ Education } & Bachelor's degree & $84 \%$ \\
\hline & Master's degree & $12 \%$ \\
\hline & Doctoral degree & $4 \%$ \\
\hline \multirow{6}{*}{$\begin{array}{c}\text { Grades } \\
\text { taught }\end{array}$} & JHS grade 1 & $24 \%$ \\
\hline & JHS grade 2 & $18 \%$ \\
\hline & JHS grade 3 & $14 \%$ \\
\hline & SHS grade 1 & $14 \%$ \\
\hline & SHS grade 2 & $14 \%$ \\
\hline & SHS grade 3 & $16 \%$ \\
\hline \multirow{4}{*}{$\begin{array}{l}\text { Teaching } \\
\text { experience } \\
\text { (years) }\end{array}$} & $1-10$ & $12 \%$ \\
\hline & $11-20$ & $72 \%$ \\
\hline & $21-30$ & $8 \%$ \\
\hline & $>30$ & $8 \%$ \\
\hline \multirow[t]{4}{*}{ age } & $20-25$ & $4 \%$ \\
\hline & $26-35$ & $34 \%$ \\
\hline & $36-45$ & $56 \%$ \\
\hline & $46-55$ & $6 \%$ \\
\hline \multirow[t]{4}{*}{ Class size } & $<30$ & $78 \%$ \\
\hline & $31-40$ & $22 \%$ \\
\hline & $41-50$ & \\
\hline & $>50$ & \\
\hline \multirow{2}{*}{$\begin{array}{l}\text { School } \\
\text { category }\end{array}$} & District/ sub- district & $58 \%$ \\
\hline & City/ town & $62 \%$ \\
\hline
\end{tabular}




\subsubsection{Indonesian EFL teachers' computer and internet use as an aid to teaching}

The numbers on the left of figure 1 below show each item asked in the questionnaire to 50 teachers. They are: (1) Owning a computer, (2) having access to computers at school, (3) computers connected to the internet, (4) having computer classrooms at school, (5) computer classrooms connected to the internet, (6) freedom to use computer classrooms at any time, (7) having received teacher training on ICT, (8) obtaining IT knowledge and skill certificate, (9) using computers when teaching, and (10) having computers access in the classrooms.

From figure 1, we can see the diversity of the data. $75 \%$ of teachers own computers but only $23 \%$ of teachers have access to the school computers. The data explain that few schools have computer units, and not all teachers can freely access and use them at schools. Then, only $23 \%$ of teachers wrote that their personal computers can be connected to the internet. This condition means that their schools provide $\mathrm{Wi}-\mathrm{Fi}$ so that the internet could be accessed by teachers who have personal computers. Meanwhile, $82 \%$ of teachers informed that their school has computer classrooms, where $62 \%$ of them are automatically connected to the school internet/Wi-Fi. Then, 35\% of them revealed that the computer classrooms can be used freely by English teachers and students during English lesson hours if the rooms are not occupied by other classes. $68 \%$ of teachers admit to having attended teacher training on ICT and $42 \%$ of them already have sufficient knowledge about ICT and certificates.

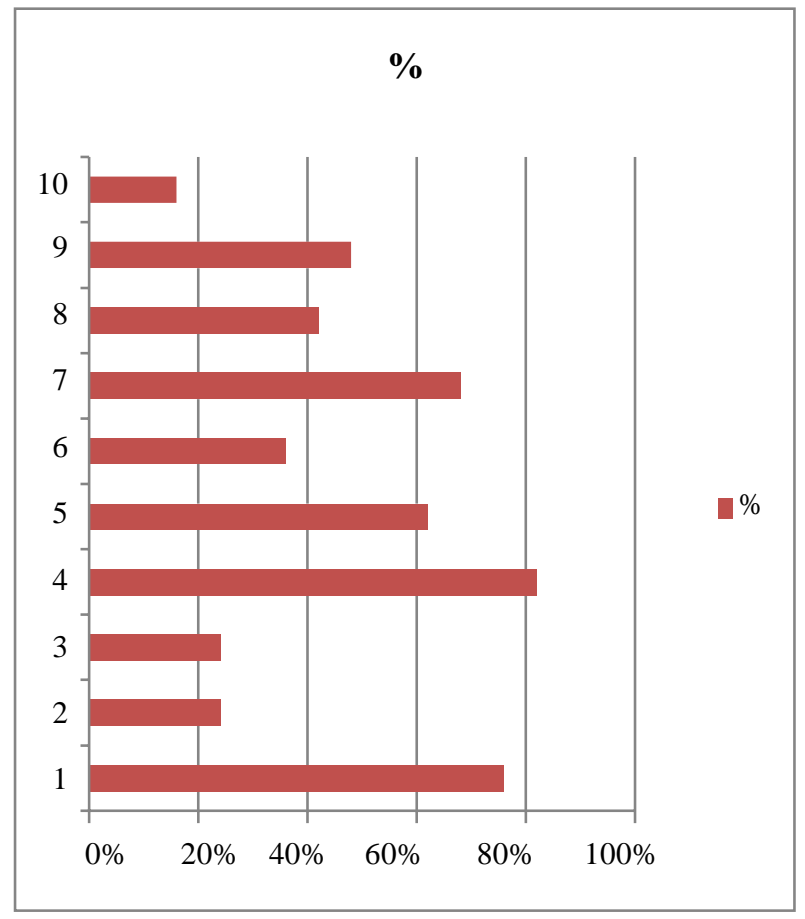

Figure 1 Indonesian EFL teachers' computer and internet use as an aid to teaching.
However, despite the large number of teachers who have personal computers, only $49 \%$ use them as teaching aids. Finally, only $17 \%$ of teachers confirmed the access for both teachers and students to use computers in the classrooms.

\subsubsection{Teachers' reasons for integrating or ignoring the use of technology when teaching}

From the results of FGI with the first 5 teachers who used technology in teaching about the reasons that underlie them to utilize it in the teaching of English, some prominent excerpts were obtained. The first teacher stated, "At first I was not interested in computers and the internet. However, I once used PowerPoint slides in teaching narrative text and the results were amazing. Students were fully involved in learning..." (Nova). From this teacher's explanation, it can be seen that he admitted the benefit of a simple feature on her computer after realizing the full involvement of students in the learning process. Meanwhile, besides the students engagement, Rio explained that the use of technology also saved time in teaching. He said, "At that time the topic was difficult but somehow it was easy, which was about "modality," I asked students to bring their smartphones to the class. I asked them to look for information about their dreaming countries then mention the rules implemented in that country to be presented in groups in front of the class. Very efficient. The students enjoyed it." Another teacher mentioned that technology helped to fulfil the students' various learning styles. He said, “..., I displayed an English dictionary and vocabulary pronunciation on the projector screen. When students had pronunciation errors, I asked them to check and imitate the pronunciation on my laptop. It is better to help my students who are very diverse in learning styles." (Ryan).

Based on this FGI, the teachers showed their enthusiasm that technology brings the ease of teaching English in the class. They agreed that technology can not only be interpreted as a new luxury output tool. However, smartphones and computers alone have greatly helped students' teaching and learning process provided teachers are ready to prepare the learning content before entering the classroom. Three teachers also described their schools as well-equipped schools where the principals and the school committees always support and listen to all the aspirations and needs of the teachers to achieve the school's vision and mission.

On the other hand, the analysis of the interviews with 5 other teachers who did not use technology in teaching English also yields some following reasons. The first teacher, Ria, said, "My school is rural ... The children are not familiar with gadgets either. So I am more comfortable teaching with books." Then, Neni raised her objection to use technology in teaching 
English because she felt that she is too old to be creative and that technology should be used by young teachers, "I am an old teacher. From the first, what I understood was to teach like this, like what my teachers used to do. Let the young ones work." Lack of knowledge and skills about using technology is also another reason why Nissa chose to teach without using technology while teaching. She described, "One day I was much panicked because the computer I was using suddenly stopped operating, and it was a school computer. I'm catchy. Fear something bad happened". From the results of the second round of FGI, the five teachers revealed that they did not like to teach with technology because it is considered as complicated. They viewed that technology was more appropriate to be used only by young teachers. The five teachers explained that they have already received ICT training several times, but they still thought that teaching English with technology is a time and mental drain. They believed that real practices such as drilling, studying in nature, and learning texts through reading aloud from books are the main things.

\subsection{Discussion}

The finding that many teachers have personal computers but only about 50 percent use them in teaching seems related to several important ideas. According to Fabry and Higgs (1997), this phenomenon is acceptable because, in fact, teachers must understand the basic skills required in computer operation, including handling problems that may arise unpredictably. This means that teaching approaches and methods may also change from teaching without using technology. The data from the questionnaires show that more than $80 \%$ of teachers have computer classrooms in schools where access to using these rooms when teaching English is limited. Besides, most classrooms are not supported by the provision of computer units so that neither teachers nor students have sufficient access to them. This situation is also explained by Kopcha (2012) who says that the use of technology as a learning medium for teachers is closely related to the availability of the ICT unit and also other factors such as plug-in problems and internet connection.

The use of technology appears to be different in each school or region and is caused by many internal and external factors as explained in the remainder section of this paper. A study conducted by Cahyani and Cahyono (2012) in a province different from where the current study was conducted shows that most teachers have used technology. They were used to using computer applications and PowerPoint presentations in their daily teaching because they were supported by school facilities including the internet networks, the willingness, and the teachers' skills.

The excerpts from the teachers who used technology in teaching lead to some related points. At least 4 prominent factors motivating them to use technology were identified from the focus group interviews. At the very least, these factors reflect the teachers' confession regarding:

1. Student engagement and motivation to study;

2. Ease and efficiency in the delivery of subject matter;

3. Fulfilment of student individual needs because visuals and sounds tend to help students learn better; and

4. The popularity of ICT in EFL learning. Apart from the above factors, 3 teachers mentioned the issue that foreign language learning, in this context, is English, is widely practiced through online media such as YouTube and various other social media using computers, laptops, and gadgets. 1 teacher also explained that there is an emphasis on the use of technology as a learning medium in the 2013 curriculum which distinguishes it from the previous curriculum.

As a basic requirement in ESL/ EFL learning, several scholars (Dudeney \& Hockly, 2007; Williams, 2005) argue that technology should be used in teaching. Some obvious roles are to help students take part in the negotiation of meanings (Jung, 2006; Kern, Ware, \& Warschauer, 2008), enhance student literacy work (Merchant, 2003), and provide a lot of other benefits so that students learn better related to encouragement, nurture, higher-order thinking skills, as well as communication and inquiry skills (Pelgrum, 2001).

A study conducted by Aydin (2012) informed that 157 EFL teachers in Turkey had positive views and attitudes towards the use of technology, but most of them, in fact, had little knowledge and understanding of computer features and experience difficulties when using them. This finding implies the importance of ICT training given to teachers and prospective teachers. In Indonesia, a study conducted by Cahyani and Cahyono (2012) concluded that Indonesian English teachers in a province, in general, strongly agreed that technology should be employed in teaching and learning processes related to convenience and student engagement as found in this study. One input that was emphasized by the respondents in Cahyani and Cahyono's research was that the availability of technology in the classroom where teachers teach will greatly facilitate them in utilizing the technology.

Based on FGI with 5 other teachers who did not use technology in teaching, their reasons can be categorized into several larger issues involving:

1. student unfamiliarity with gadgets and technology;

2. openness to the importance of adaptation to the times which greatly affects student needs and learning styles. Based on the explanation obtained from the interview, 1 teacher showed that he was skeptical 
about learning English using technology, "I am an old teacher. From the first, what I understood was to teach like this, like what my teachers used to do. Let the young ones work."; and

3. Lack of knowledge and skills about technology, especially the operation of features on computers, errors, and those unpredictable problems.

Furthermore, two teachers in their explanation said that this was a big obstacle that would take up learning time. On the other hand, they must ensure that the material is thoroughly taught to the students and understood by them within a limited duration.

Regarding the reasons for teachers who chose not to use technology in teaching, as revealed in the introduction section, Ertmer (1999) mentions these reasons as "barriers" which are classified into 2 types. Planning, access, and technical support are first-order barriers while teachers' beliefs about technology, instructional models, and closeness to change and development as happened to one teacher in this study are categorized into second-order barriers. It appears that these barriers are considered as lingering issues and should be well-managed. In a study conducted by Muslem, Yusuf, and Juliana (2018) on Indonesian English teachers' barriers to use ICT in 16 public senior high schools, both categories of barriers faced by teachers emerged. They include lack of time and tools, lack of knowledge, skills, and experience in utilizing technology as well as no or poor internet connection. Behind this phenomenon, this situation shows that the improvement to the use of technology by teachers must be well-addressed.

\section{CONCLUSION}

Technology as one of the important aspects of learning support should be utilized appropriately and proficiently by English teachers. 21-st century learning requires teachers to be able to empower technology to keep pace with the times and the students as digital natives. As a first step, training in ICT and technology such as the use of computers and the internet in the teaching of English is seen as necessary. This training is also expected to change the paradigm of some teachers who think that technology makes teaching and learning more complicated. This research shows that teachers' use of computers and the internet is still low, and several reasons underlie it related to personal issues and beliefs, facilities, school principals, committees, and students. We propose that this kind of support could be nurtured through professional development activities that are particular to the EFL learning context.

Notwithstanding the findings revealed in this research, the participants in this research are limited, and therefore the research result cannot be generalized.
Expanding the participants' number will be suggested for further research to be done.

\section{REFERENCES}

Aydin, S. (2012). A review of research on Facebook as an educational environment. Educational Technology research and development, 60(6), 1093-1106.

Bai, H., \& Ertmer, P. A. (2008). Teacher educators' beliefs and technology uses as predictors of preservice teachers' beliefs and technology attitudes. Journal of Technology and Teacher Education, 16(1), 93-112.

Billah, A. F. M. T. (2015). Pemanfaatan media teknologi informasi dan komunikasi dalam implementasi kurikulum 2013: Studi deskriptif pada pembelajaran bahasa Inggris di Sekolah Menengah Atas Negeri se-Kota Bandung. (Doctoral's dissertation). Universitas Pendidikan Indonesia, Bandung, Indonesia. Retrieved from https://repository.upi.edu.

Cahyani, H., \& Cahyono, B. Y. (2012). Teachers' attitudes and technology use in Indonesian EFL classrooms. TEFLIN Journal, 23(2), 130-148.

Chapelle, C. A. (2003). English language learning and technology: Lectures on applied linguistics in the age of information and communication technology. Amsterdam: John Benjamins.

Cuban, L., Kirkpatrick, H., \& Peck, C. (2001). High access and low use of technologies in high school classrooms: Explaining an apparent paradox. American Educational Research Journal, 38(8), $13-34$.

Davies, R. S., \& West, R. E. (2014). Technology integration in schools. In Handbook of research on educational communications and technology (pp. 841-853). Springer, New York, NY.

Dudeney, G., \& Hockly, N. (2007). How to Teach English with Technology. England: Longman.

Ertmer, P. A. (1999). Addressing first-and second-order barriers to change: Strategies for technology integration. Educational technology research and development, 47(4), 47-61.

Fabry, D. L., \& Higgs, J. R. (1997). Barriers to the effective use of technology in education: Current status. Journal of educational computing research, 17(4), 385-395.

Garcia, P., \& Rose, S. (2007). The influence of technocentric collaboration on preservice teachers' attitudes about technology's role in powerful 
learning and teaching. Journal of Technology and Teacher Education, 15(2), 247-266.

Jung, S. H. (2006). The Use of ICT in Learning English as an International Language. (Doctoral's dissertation). University of Maryland. Retrieved from http:// Education.uci.edu/Person/warshauerin/docs/networksed.pdf.

Kern, R., Ware, P., \& Warschauer, M. (2008). Networkbased language teaching. Encyclopedia of language and education, 4, 281-292.

Kopcha, T. J. (2012). Teachers' perceptions of the barriers to technology integration and practices with technology under situated professional development. Computers \& Education, 59(4), 1109-1121.

http://dx.doi.org/10.1016/j.compedu.2012.05.014

Koster, B., Dengerink, J., Korthagen, F., \& Lunenberg, M. (2008) Teacher educators working on their own professional development: goals, activities and outcomes of a project for the professional development of teacher educators. Teachers and Teaching, 14(5-6), 567-587. doi: $10.1080 / 13540600802571411$

Li, L., \& Walsh, S. (2011). Technology uptake in Chinese EFL classes. Language Teaching Research, 15(1), 99-125. https://doi.org/10.1177/1362168810383347

Merchant, G. (2003). E-mail me your thoughts: Digital communic-ation and narrative writing. Reading, 37(3), 104-110. doi: 10.1046/j.00340472.2003.03703003.

Muslem, A., Yusuf, Y. Q., \& Juliana, R. (2018). Perceptions and barriers to ICT use among English teachers in Indonesia. Teaching English with Technology, 18(1), 3-23.

Pelgrum, W. J. (2001). Obstacles to the integration of ICT in education: results from a worldwide educational assessment. Computers \& Education, 37(2), 163-178.

Warschauer, M. \& Healey, D. (1998). Computers and language learning: An overview. Language Teaching, 31(2), 57-71.

Williams, J. N. (2005). Learning without awareness. Studies in Second Language Acquisition, 27, 269 304. 